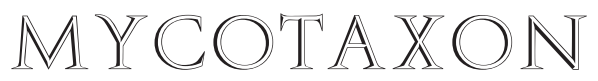

Volume 111, pp. 131-141

January-March 2010

\title{
New records in the Tubeufiaceae from Andean Patagonian forests of Argentina
}

\author{
Romina M. SÁnChez \& M. Virginia BianchinotTi \\ rsanchez@uns.edu.ar\&vbianchi@uns.edu.ar \\ Lab. Ficología y Micología, DBByF, \\ Universidad Nacional del Sur. LEBBAH, CERZOS (CONICET), \\ Edificio E1, Camino La Carrindanga, Km7, B8000FWB, Bahía Blanca, Argentina
}

\begin{abstract}
Tubeufiaceae (Pleosporales, Ascomycota) occurring on native trees from the Andean Patagonian forests in Argentina are described and illustrated. Acanthostigma minutum and Tubeufia cerea with its anamorphic state are reported from South America for the first time on Nothofagus dombeyi and N. antarctica, respectively. Both species were up to now only known from the Northern Hemisphere.
\end{abstract}

Key words - ascomycetes, Helicosporium, Nothofagaceae

\section{Introduction}

Barr (1979) erected the family Tubeufiaceae to accommodate several genera of Pleosporales that are saprobic on wood, hypersaprobic or hyperparasitic on other fungi, or parasitic on scale insects. The ascomata are small, pallid yellowish to brownish, globose, conic, ellipsoid or cylindrical. She included six genera in the family: the type genus Tubeufia, Letendraea Sacc., Melioliphila Speg., Podonectria Petch, Rebentischia P. Karst., and Thaxteriella Petr. Later, Barr (1980) added five more genera - Allonecte Syd., Boerlagiomyces Butzin, Byssocallis Syd., Paranectriella (Henn. ex Sacc. \& D. Sacc.) Höhn., and Puttemansia Henn. - and synonymized Thaxteriella with Tubeufia.

The classification of the Tubeufiaceae, mainly based on morphology, has been controversial. Eriksson (2005) placed this family as "Dothideomycetes et Chaetothyriomycetes incertae sedis". Based on sequence analyses Kodsueb et al. (2006) considered the Tubeufiaceae a distinct monophyletic family that clusters within the Pleosporales as originally proposed by Barr (1980) and excluded Boerlagiomyces and Letendraea as phylogenetically unrelated. At the same time Tsui \& Berbee (2006) arrived at similar results analyzing molecular data of several Tubeufia taxa and helicosporous fungi that are considered anamorphic 
states of Acanthostigma and Tubeufia. They indicated that many Tubeufia spp. and most species of Helicoma, Helicomyces, and Helicosporium lay within a strongly supported monophyletic lineage, the Tubeufiaceae sensu stricto.

Most species of Tubeufiaceae are considered tropical, but there are species that occur primarily in temperate areas (Hughes 1978; Rossman 1979, 1987; Samuels et al. 1978). Additional austral records are known in Argentina, Brazil, Chile, and Paraguay, i.e. four Acanthostigma species described by Spegazzini (1884, 1887, 1899, 1909), Rebentischia costi in Brazil (Batista et al. 1963), and Rebentischia massalongoi recently recorded in Argentina (Bianchinotti \& Sánchez 2009).

Rebentischia is an accepted member of Tubeufiaceae (Kodsueb et al. 2006) but the position of Acanthostigma is doubtful. De Notaris established the genus in 1863 with A. perpusillum as type. From the beginning its taxonomic status was confused, with the genus referred first to the Sphaeriaceae by Saccardo (1883), to the Trichosphaeriaceae by Ellis \& Everhart (1892), and then synonymized with Tubeufia by Arx \& Müller (1975). Barr (1980) regarded Acanthostigma as a section in Tubeufia but later (Barr 1990, 1993) returned it to the Trichosphaeriaceae based on its unitunicate asci. Crane et al. (1998) established another genus in the Tubeufiaceae, Acanthostigmina Höhn. More recently, Réblová \& Barr (2000) examined the type material of Acanthostigma and confirmed its position in Tubeufiaceae, citing Acanthostigmina as a synonym. Tsui et al. (2006) found that A. perpusillum clusters with Tubeufia cerea, and they suggested that Tubeufia should be synonymized under Acanthostigma.

We have re-examined the specimens representing Acanthostigma described by Spegazzini that have not been included in former revisions of the genus. Also, we describe and illustrate other representatives of the Tubeufiaceae s.l. collected on native trees from the Andean Patagonian forests. Acanthostigma and Tubeufia are recorded for the first time in Argentina, with Acanthostigma minutum and Tubeufia cerea reported for the first time in South America. These new records expand the geographical distribution of the family to the most austral point.

\section{Materials and methods}

The samples were collected in forests of Los Alerces National Park (Chubut) and Lanín National Park (Neuquén) located in the southern Andes of Patagonia (Argentina). The vegetation is composed mostly of native Nothofagus species together with some species of Cupressaceae, Proteaceae, ferns and mosses. The climate is temperate to cold with high humidity. Leaves, small branches and bark showing fungal growth when observed with a field magnifying glass were placed in paper bags and transported to the laboratory. The samples were dried at room temperature and deposited at Bahía Blanca Biology Herbarium 
(BBB). For microscopic examinations sections were hand-made and mounted in water or $5 \% \mathrm{KOH}$ with phloxine. At least ten measurements were taken for each structure and all were made in tap water. Calcofluor $1 \%$ was used for the examinations made under the fluorescence microscope. The LPS and NYBG Herbaria provided type material. Herbarium abbreviations follow Holmgren et al. (1990). The term " $x_{a v}$ " represents the average dimension.

\section{Results and discussion}

Acanthostigma De Not., Sfer. Ital., Cent. I, Fasc. 2: 85. 1863.

TyPe SPECIES: A. perpusillum De Not.

Acanthostigma minutum (Fuckel) Sacc., Syll. Fung. 2: 209. 1883.

FIGS. 1-7

AsсоматA superficial to semi-immersed under periderm, globose to subglobose, dark brown to black when dried, (95-)110-300(-350) $\times 100-300(-330) \mu \mathrm{m}$; ostiole papillate, $61-112.5 \times 35.7-47.5 \mu \mathrm{m}$; surface covered with setae, straight or curved, most densely distributed on upper half, $0-1$ septate, dark brown, 46-130 $\mu \mathrm{m}$ long $\left(x_{a v}=79 \mu \mathrm{m}\right), 3-8.2 \mu \mathrm{m}$ wide at base $\left(x_{a v}=6 \mu \mathrm{m}\right), 1-3.8 \mu \mathrm{m}$ wide at apex $\left(x_{a v}=1.9 \mu \mathrm{m}\right)$. PERIDIUM of textura angularis, two-layered in longitudinal section, outer layer composed of 3-5 rows of thick-walled, dark brown cells, inner layer composed of 2-4 rows of light brown cells, $18-55 \mu \mathrm{m}$ thick $\left(x_{a v}=35 \mu \mathrm{m}\right)$. PSEUDOPARAPHYSES cellular ramified, anastomosed, septate, hyaline, $1-3 \mu \mathrm{m}$ thick. PERIPHYSOIDES cellular ramified, septate, hyaline, ca. $2.5 \mu \mathrm{m}$ thick. ASCI bitunicate, cylindrical to clavate, $80-150 \times 12-50 \mu \mathrm{m}\left(x_{a v}\right.$ $=116 \times 22 \mu \mathrm{m}), 8$-spored. ASCOSPORES elongate fusiform, tapering to ends and rounded, symmetric, straight or slightly curved, (7-) $9(-12)$ septate, not constricted or slightly constricted at septa, hyaline, smooth, 35-68(-75) $\times 5-8$ $\mu \mathrm{m}\left(x_{a v}=50 \times 6.8 \mu \mathrm{m}\right)$. ANAMORPH - Helicomyces sp. (not seen).

Distribution - America (Argentina, Canada, USA); Asia (China, Taiwan); Europe (France, Germany, Switzerland).

ECOLOGY - on decaying wood of deciduous trees and woody, dicotyledonous shrubs and on old ascomata of other ascomycetes. Recorded on Fagus sylvatica L., Gaultheria shallon Pursh, Nothofagus dombeyi (Mirb.) Oerst., Populus sp., and Quercus sp.

Material exAmined - ARGENTINA: Neuquén, Parque Nacional Lanín, on the way to Hui Hui lake, on old xylariaceous stromata on bark of Nothofagus dombeyi, 17. V. 2007, leg. MV Bianchinotti and RM Sánchez 579 (BBB), Paso del Cordoba, on bark of N. dombeyi, 18. I. 2009, leg. MV Bianchinotti and RM Sánchez 776 and 781 (BBB). USA: Connecticut, $1 \mathrm{mi}$ south of Canaan, on decayed wood associated with Hemitrichia clavata, 2. XI. 1959, CT Rogerson, (as Acanthostigma decastylum, NY).

Comments - Acanthostigma minutum is recorded for the first time in South America. It was found without its anamorph growing on old xylariaceous 


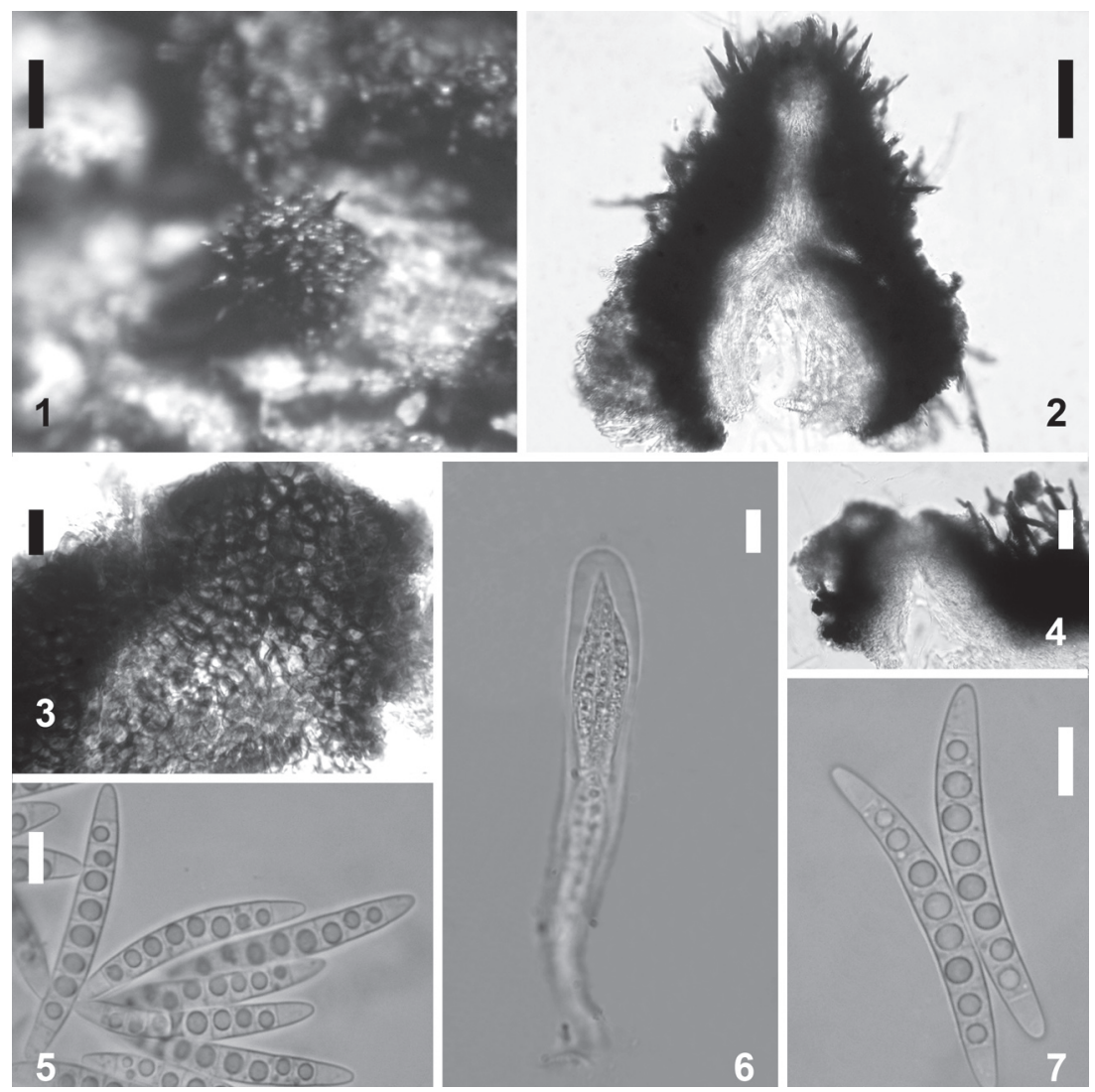

Figures 1-7. Acanthostigma minutum (from MVB-RS 579, 776 \& 781, deposited in BBB). 1. Ascoma on bark of Nothofagus dombeyi. 2. Longitudinal section. 3. Peridium. 4. Section of papilla. 5, 7. Ascospores. 6. Ascus. Bars: $1=100 \mu \mathrm{m} .2=50 \mu \mathrm{m} .4=20 \mu \mathrm{m} .3,5-7=10 \mu \mathrm{m}$

stromata on Nothofagus dombeyi logs. We compared our specimens with a collection from the USA authenticated by Réblová \& Barr (2000), which differs in having ascospores with more septa (10-14). This is the first record of the genus in Argentina.

\section{Excluded and doubtful species}

Acanthostigma dimerosporioides Speg., Anal. Mus. Nac. Bs. As. 6: 277. 1898.

FIGS. 8-9

Ascomata superficial, globose, setose, dark brown, 155-158 $\mu$ m diam, ostiole circular, $28 \mu \mathrm{m}$ diam. SETAE septate, brown, 50-250 $\times 4-5 \mu \mathrm{m}$ (fide Spegazzini 
1898). ASCI bitunicate. PSEUDOPARAPHYSES not seen. ASCOSPORES fusiform, 3-septate, dark brown, smooth, 18.5-20 ×5 $\mu \mathrm{m}$.

Material eXAmined - ARGENTINA, La Plata, on Gnaphalium purpureum, III 1899,

leg. CL Spegazzini (LPS 2667!).

Comments - The 3-septate, dark brown ascospores exclude this material from Acanthostigma. We think the specimen probably belongs to Herpotrichiellaceae.

Acanthostigma gnaphaliorum Speg., Anal. Mus. Nac. Bs. As. 19: 375. 1909.

FIGS. $10-11$

Ascomata superficial, globose, setose, dark brown, 169-170 $\mu \mathrm{m}$ diam, ostiole circular, $35 \mu \mathrm{m}$ diam. SETAE $2-8$ septate, brown to pale brown, 95-145 $\mu \mathrm{m}$ long and 3.5-5 $\mu \mathrm{m}$ wide at base. ASCI unitunicate, without any visible apical apparatus, 50-60 $\times 8 \mu \mathrm{m}$. PSEUDOPARAPHYSES not seen. ASCOSPORES fusiform, with one inner cell slightly broader, 3-septate, pale brown, smooth.

MATERIAL EXAMINED - ARGENTINA, La Plata, Ensenada, on Gnaphalium purpureum, 28. XI. 1906, leg. CL Spegazzini (LPS 2391!).

Comments - Only immature ascospores still in the asci were seen. Spegazzini described it as aparaphysate. This species does not belong to the Tubeufiaceae because of the combination of unitunicate asci and 3-septate, pale brown ascospores. It resembles members of the Chaetosphaeriaceae.

Acanthostigma imperspicuum Speg., Bol. Acad. Nac. Ci. Córdoba 11: 46.1887.

FIGS. 12-16

Ascomata superficial, globose, setose, reddish dark brown, 189-202 $\mu \mathrm{m}$ diam. SETAE dark brown, $38 \mu \mathrm{m}$ long. ASCI not seen. AsCOSPORES fusiform, with one inner cell slightly broader, 3-septate, pale brown, smooth, 13-16 × 4-5 $\mu \mathrm{m}$.

Material examined - CHILE, Patagonia, Cabo Negro, on Fagus antarcticum [ $\equiv$ Nothofagus antarctica], VI 1886, leg. CL Spegazzini (LPS 87!).

Comments - The material is in poor condition and has no asci; however, Spegazzini illustrated the asci as unitunicate. Because of the combination of characters, it probably belongs in the Chaetosphaeriaceae.

Acanthostigma guaraniticum Speg., Anal. Soc. Ci. Argent. 18(6): 286. 1884.

FIGS. 17-20

Material eXAmined - PARAGUAY, Caá-Guazú, on Eugenia sp., Leg. Balanza 3452, I

1882, det. CL Spegazzini (LPS 2664!).

Comments - This material is very scarce and consists of a single, small leaf of Eugenia sp. We could not find any ascomata. Brown conidiophores were observed, but no conidia were found. According to Spegazzini's drawings on the type envelope (available also in Arambarri et al. 2008), this species resembles 

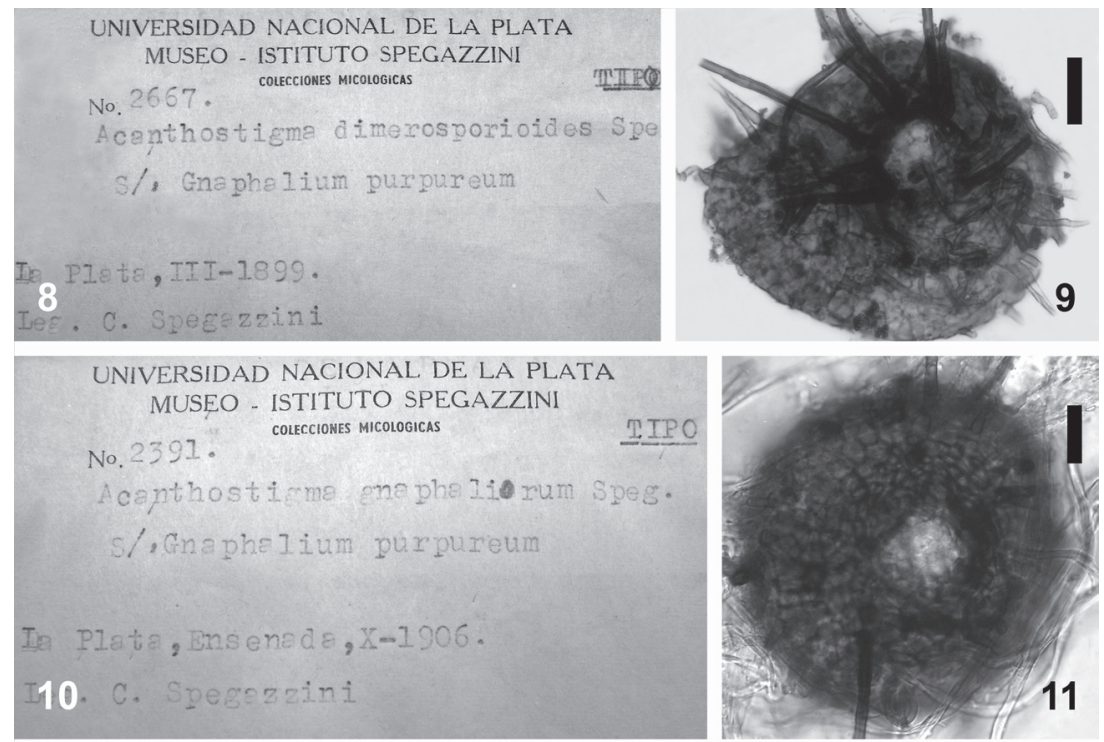

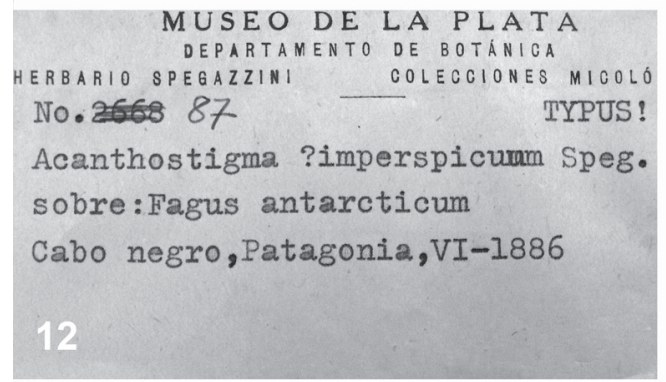
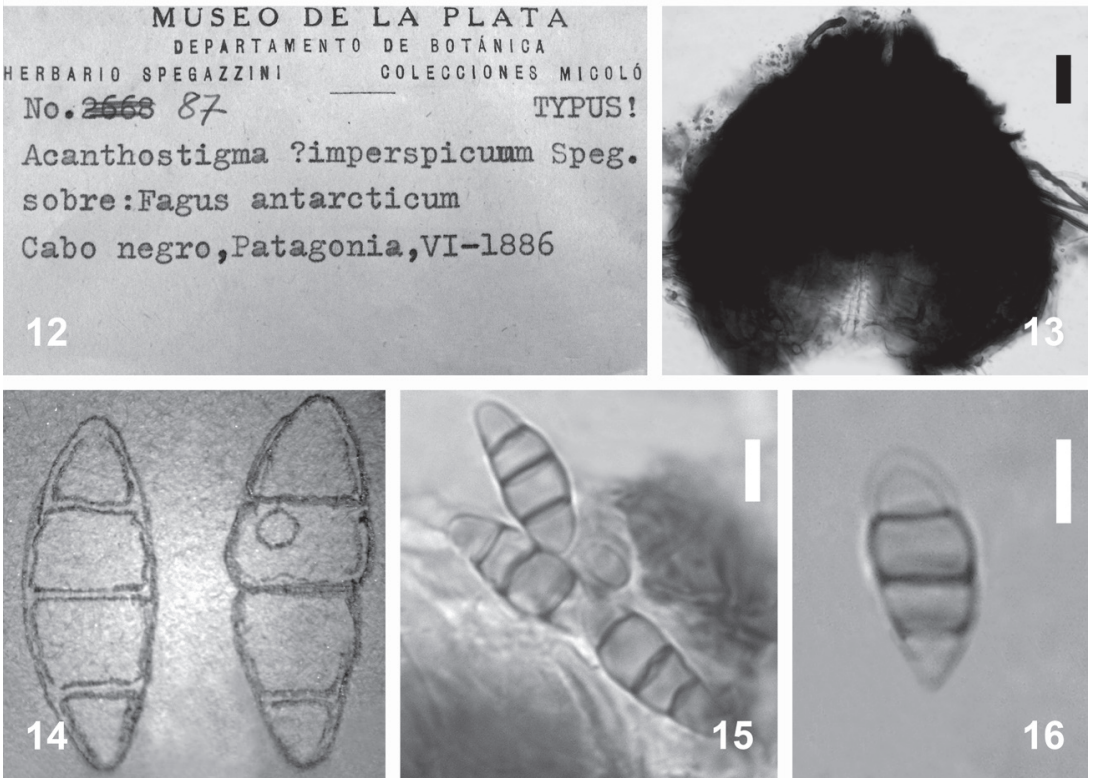

Figures 8-16. Spegazzini's herbarium material (from LPS). 8, 10 and 12. Envelopes of the types. 8-9. Acanthostigma dimerosporioides (LPS 2667!). 9. Ascoma top view. 10-11. A. gnaphaliorum (LPS 2391!). 11. Ascoma top view. 12-16. A. imperspicuum (LPS 87!). 13. Ascoma side view. 14. Drawing of ascospores done by Spegazzini on type envelope. 15-16. Ascospores (LPS 87!). Bars: $9,11,13=20 \mu \mathrm{m} .15-16=3 \mu \mathrm{m}$. 

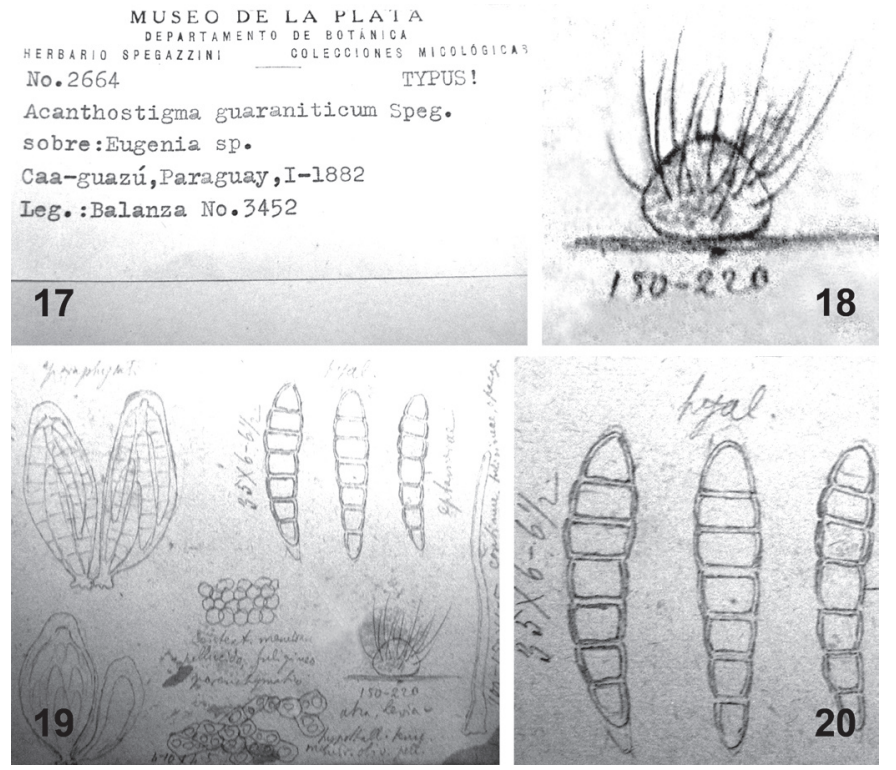

FIgURES 17-20. Acanthostigma guaraniticum (from LPS 2664!). 17. Envelope of the type. 18-20. Original illustrations from type envelope. 18. Superficial and setose ascoma. 19. Summary of all the structures and tissues. 20. Ascospores.

a true Acanthostigma. However, Spegazzini described the asci as unitunicate (Spegazzini 1884) so, until authentic material is located, this should be treated as a species dubia.

Tubeufia Penz. \& Sacc., Malpighia 11: 517. 1897.

TyPe SPECIEs: T. javanica Penz. \& Sacc. [= T. paludosa (P. Crouan \& H. Crouan) Rossman].

Tubeufia cerea (Berk. \& M.A. Curtis) Höhn., Sitzungsber. Akad. Wiss., Math.-Naturwiss. Kl., Abt. 1, 128: 562. 1919.

FIGS. 21-36

Ascomata globose or collabent when dried, bright yellow becoming yellowish brown towards base, a little darker in depression around the papilla, 170-225 $\times 80-215 \mu \mathrm{m}\left(x_{a v}=200 \times 130 \mu \mathrm{m}\right)$; papilla 30-50 $\times 55-100 \mu \mathrm{m}\left(x_{a v}=40 \times\right.$ $77.5 \mu \mathrm{m})$; ostiole circular, $30-40.8 \mu \mathrm{m}\left(x_{a v}=36 \mu \mathrm{m}\right)$; surface pulverulent with protruding conical cells, sometimes curved, with 1-3 septa, yellow, 5-8 $\times 4-5$ $\mu \mathrm{m}$. PERIDIUM $20-50 \mu \mathrm{m}$ thick $\left(x_{a v}=36 \mu \mathrm{m}\right)$, forming textura angularis, cells $5-$ $10 \times 3-8 \mu \mathrm{m}\left(x_{a v}=7.6 \times 5 \mu \mathrm{m}\right)$. Asci bitunicate, cylindrical to claviform, 76-87 $\times 10-13 \mu \mathrm{m}\left(x_{a v}=81.4 \times 11.4 \mu \mathrm{m}\right)$. PSEUDOPARAPHYSES narrow, ramified, parallel or somewhat interwoven, septate, $1-2 \mu \mathrm{m}$ thick. AscosPoRES elongate fusiform, often curved, apices acute, 6-11 septate, not constricted at septa, hyaline or slightly yellowish, smooth, $38.8-58 \times 3-6 \mu \mathrm{m}\left(x_{a v}=48.7 \times 4 \mu \mathrm{m}\right)$. 

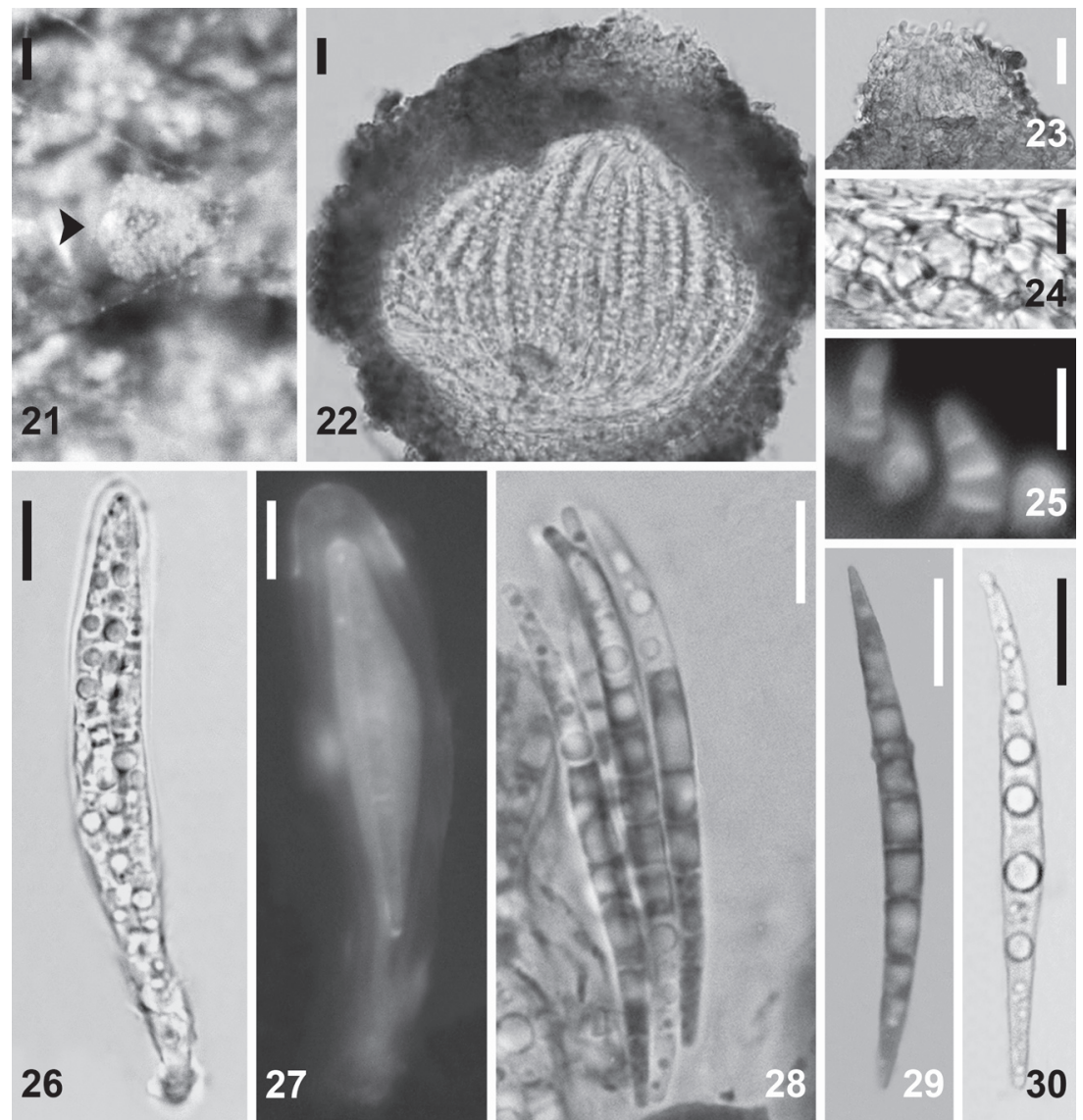

Figures 21-30. Tubeufia cerea (from MVB-RS 564, deposited in BBB). 21. Ascoma (arrow head) on bark of Nothofagus antarctica. 22. Longitudinal section. 23. Papilla. 24. Peridium. 25. Protruding conical cells of the ascomal wall showing the septa using fluorescence microscopy. 26. Ascus 8 -spored (in water). 27. Ascus viewed with fluorescence microscopy. 28-30. Ascospores (28-29 in phloxine, 30 in water).

Bars: $21=50 \mu \mathrm{m}, 23=20 \mu \mathrm{m}, 22,26-30=10 \mu \mathrm{m}, 24-25=5 \mu \mathrm{m}$.

ANAmorph - Helicosporium virescens (Pers.) Sivan. Colonies effuse, forming a loose, cottony layer, yellow to greenish yellow. MYCELIUM scarcely ramified, hyaline to pale brown, $2-10 \mu \mathrm{m}$ wide. CONIDIOPHOREs erect, unbranched, dark brown basally, pale brown to hyaline towards the setiform sterile apex, 61-210 $\mu \mathrm{m}$ long, $2.5-10 \mu \mathrm{m}$ wide at base, $2-2.5 \mu \mathrm{m}$ wide at apex. Conidiogenous CELLS integrated, mono or polyblastic, $7-21 \times 2-3 \mu \mathrm{m}$. CONIDIA cochleated, coiled 2-3 times, multiseptate, hyaline, smooth, coils $10-21 \mu \mathrm{m}$ diam $\left(x_{a v}=\right.$ $16.6 \mu \mathrm{m})$, cells $1.5-2 \mu \mathrm{m}$ wide. 

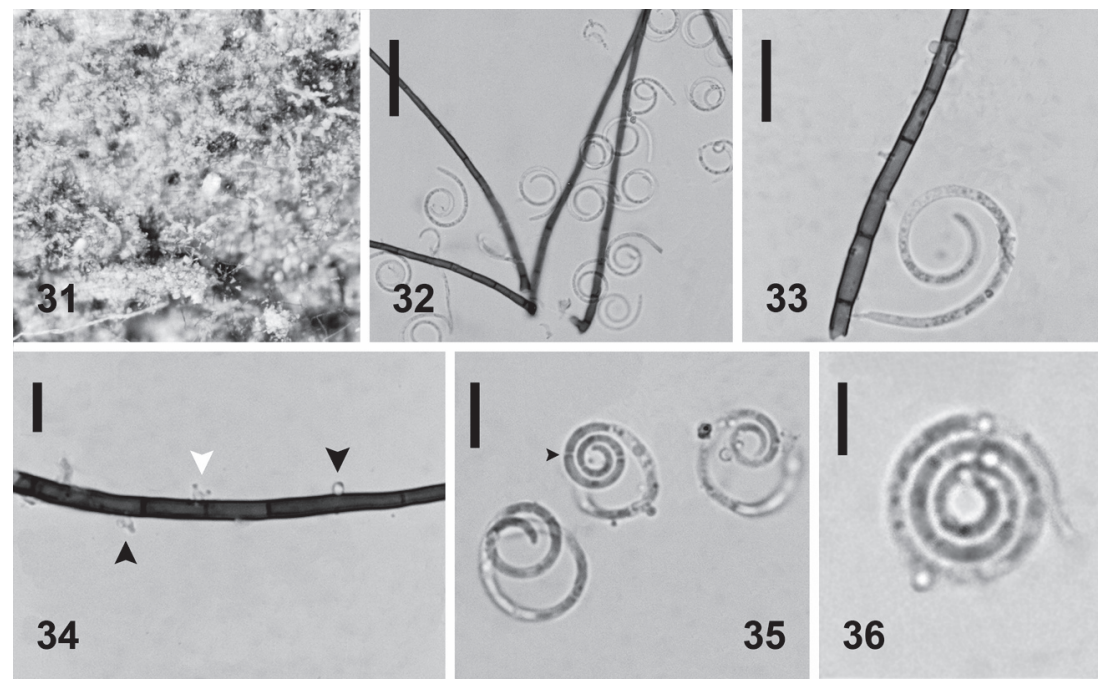

FIGURES 31-36. Tubeufia cerea anamorph: Helicosporium virescens (from MVB-RS 564, deposited in BBB). 31. Colony on Nothofagus antarctica. 32. Conidiophores and conidia. 33. Conidium attached to conidiophore. 34. Conidiophore showing two monoblastic conidiogenous denticles (black arrows) and a polyblastic denticle (white arrow). 35. Conidia with septa (arrow points to a septum). 36. Conidia coiled three times.

Bars: $32=20 \mu \mathrm{m} .33-35=10 \mu \mathrm{m} .36=5 \mu \mathrm{m}$.

Distribution - Africa (Congo); Asia (USSR, India); America (Argentina, Canada, Guyana, Puerto Rico, USA); Europe (Austria, Belgium, Finland, France, Germany, Netherlands, Poland, Portugal, Sweden, UK).

ECOLOGY - On wood and bark lying on the ground, on herbaceous substrates, and on old ascomata or mycelium of other ascomycetes.

Material EXAMINED - ARGENTINA, Neuquén, Parque Nacional Lanín, RN 234 near Villa Traful access route, on log of Nothofagus antarctica (G. Forst) Oerst., 16. V. 2007, leg. MV Bianchinotti and RM Sánchez 564 (BBB).

Comments - The genus Tubeufia was erected in 1897 by Penzig and Saccardo to accommodate three species from Java (i.e., T. javanica, T. coronata, T. anceps) characterized by white, cream-pink to brownish, vertically oblong to ovoid ascomata and cylindrical, fusiform to vermiform, multiseptate ascospores.

This is the first record of Tubeufia in Argentina and the first time that Tubeufia cerea is recorded in South America. Our material differs from that described by Munk (1957) in having larger ascospores $(36-48 \times 2.5-3.5 \mu \mathrm{m})$. Tubeufia cerea is widely distributed in temperate areas in the Northern Hemisphere, with a few records from the tropics (Cannon 1999). This is the first report of this species in the subpolar zone. 
Other species of Tubeufia previously recorded in South America are T. albo-ostiolata Rossman in Venezuela, T. amazonensis Samuels et al. in Brazil, and T. aurantiella (Penz. \& Sacc.) Rossman, T. cylindrothecia (Seaver) Höhn., T. helicoma (W. Phillps \& Plowr.) Piroz., T. palmarum (Torrend) Samuels et al., and T. paludosa in Brazil and Venezuela (Rossman 1987, Samuels et al. 1978).

\section{Acknowledgments}

The Consejo Nacional de Investigaciones Científicas y Tecnológicas (CONICET: PIP 5660) and the Universidad Nacional del Sur (UNS: PGI) are thanked for financial support. We thank LPS and NYBG Herbaria for providing the necessary materials. We are grateful to Paul F. Cannon, Andrew N. Miller, Amy Rossman and Carol A. Shearer for providing bibliographic material. Amy Rossman and Andrew N. Miller are thanked for acting as pre-submission reviewers and for their helpful comments.

\section{Literature cited}

Arambarri AM, Minter TJ, Cabello MN, Minter DW. 2008. Spegazzini - Dibujos de Hongos, una Biblioteca Digitalizada. [www.cybertruffle.org.uk/spegazzini, website accessed: 10.10.2008]

Arx JA, Müller E. 1975. A re-evaluation of the bitunicate Ascomycetes with keys to families and genera. Stud. Mycol. 9: 1-159.

Barr ME. 1979. A classification of Loculoascomycetes. Mycologia 71: 935-957.

Barr ME. 1980. On the family Tubeufiaceae (Pleosporales). Mycotaxon 12: 137-167.

Barr ME. 1990. Prodromus to nonlichenized, pyrenomycetous members of class Hymenoascomycetes. Mycotaxon 39: 43-184.

Barr ME. 1993. Redisposition of some taxa described by J.B. Ellis. Mycotaxon 46: 45-76.

Batista AC, Bezerra JL. 1963. Alguns Ascomycetes Hialofragmos de Significação Fitopatológica. Publ. Univ. Recife Inst. Micol. 385: 6-9.

Bianchinotti MV, Sánchez RM. 2009. Micromycetes on Austrocedrus chilensis. First record of Rebentischia from Argentina. Mycotaxon 107: 449-454.

Cannon PF. 1999. Tubeufia cerea. I.M.I. Description of Fungi and Bacteria 1409: 1-2.

Crane JL, Shearer CA, Barr ME. 1998. A revision of Boerlagiomyces with notes and a key to the saprobic genera of Tubeufiaceae. Can. J. Bot. 76: 602-612.

Ellis JB, Everhart BM. 1892. The North American Pyrenomycetes. Ellis \& Everhart, Newfield, New Jersey. (USA). $793 \mathrm{p}$.

Eriksson OE. 2005. Outline of Ascomycota - 2005. Myconet 11:1-113.

Holmgren PK, Holmgren NH, Barnett LC. 1990. Index herbariorum: Part I: Herbaria of the World. $8^{\text {th }}$ ed. Bronx, New York Botanical Garden.

Hughes SJ. 1978. New Zealand fungi 25. Miscellaneous species. New Zeal. J. Bot. 16: 311-370.

Kodsueb R, Jeewon R, Vijaykrishna D, McKenzie EHC, Lumyong P, Lumyong S, Hyde KD. 2006. Systematic revision of Tubeufiaceae based on morphological and molecular data. Fungal Divers. 21: $105-130$.

Munk A. 1957. Danish pyrenomycetes. A preliminary flora. Dansk Bot Ark 17: 1-478.

Réblová M, Barr ME. 2000. The genus Acanthostigma (Tubeufiaceae, Pleosporales). Sydowia 52: 258-285. 
Rossman AY. 1979. Calonectria and its type species, C. daldiniana, a later synonym of C. pyrochroa. Mycotaxon 8: 321-328.

Rossman AY. 1987. The Tubeufiaceae and similar Loculoascomycetes. Mycol. Pap. 157: 1-71.

Saccardo PA. 1883. Pyrenomycetae. Sylloge Fungorum, Padua, (Italy) 2. 813p.

Samuels GJ, Rossman AY, Müller E. 1978. Life-history studies of Brazilian Ascomycetes 6. Sydowia 31: 1-6.

Spegazzini CL. 1884. Fungi Guaranitici. Pugillus I. Anal. Soc. Ci. Argent. 18(6): 263-286.

Spegazzini CL. 1887. Fungi Patagonici. Bol. Acad. Nac. Ci. Córdoba 11(1): 5-64.

Spegazzini CL. 1898. Fungi Argentini novi v. critici. Anal. Mus. Nac. Bs. As. 6: 81-365.

Spegazzini CL. 1909. Mycetes Argentinenses (Series IV). Anal. Mus. Nac. Bs. As. 19(12): 257-458.

Tsui CKM, Berbee ML. 2006. Phylogenetic relationships and convergence of helicosporous fungi inferred from ribosomal DNA sequences. Mol. Phyl. Evol. 39: 587-597.

Tsui CKM, Sivichai S, Berbee ML. 2006. Molecular systematics of Helicoma, Helicomyces and Helicosporium and their teleomorphs inferred from rDNA sequences. Mycologia 98: 94-104. 
